\title{
Abortion as a Moral Good? Contrasting Secular and Judeo-Christian Views and a Potential Pathway for Promoting Life
}

\author{
Brent M. Egan ${ }^{1,2}$ \\ ${ }^{1}$ Simpsonville, South Carolina, USA \\ ${ }^{2}$ Improving Health Outcomes, American Medical Association, Greenville, South Carolina, USA \\ Email: brentegan7@yahoo.com
}

How to cite this paper: Egan, B.M. (2021) Abortion as a Moral Good? Contrasting Secular and Judeo-Christian Views and a Potential Pathway for Promoting Life. Health, 13, 31-39.

https://doi.org/10.4236/health.2021.131003

Received: December 17, 2020

Accepted: January 19, 2021

Published: January 22, 2021

Copyright (๑) 2021 by author(s) and Scientific Research Publishing Inc. This work is licensed under the Creative Commons Attribution International License (CC BY 4.0).

http://creativecommons.org/licenses/by/4.0/ (c) (i) Open Access

\begin{abstract}
Objective: This review aims to summarize key facets of the Pro Choice and Pro Life perspectives and outline a resolution pathway that minimizes abortion. Main Results: Approximately 1.3 billion abortions occurred worldwide from 1990 through 2014. In the United States, more than 61 million abortions were performed between 1973 and 2017. The Pro Choice perspective posits that: 1) A fetus is not a person; therefore, a person is not harmed. 2) Forced childbearing includes significant health and psychological risks to the mother and can exacerbate poverty. Since a person is not harmed and the mother is benefited, abortion is a moral good. From a Judeo-Christian, Pro Life perspective: 1) God creates every person in his image and has a pre-conception life plan for them. 2) God commanded us to be fruitful and multiply and identified children as a blessing. Hence, abortion harms a person and is rebellion against God. Conclusion: In working toward a solution, agape love, which is sacrificial and giving, not selfish or condemning, is a good starting point. In that light, the Judeo-Christian community can begin bridging the chasm between the Pro Life and Pro Choice communities by sharing truth in love and helping to meet the material and emotional needs of pregnant women who see no alternative to abortion. Proactive, unconditional love provides the foundation for making the womb a sanctuary for life.
\end{abstract}

\section{Keywords}

Abortion, Fetus, Pro Choice, Pro Life, Maleficence, Beneficence

\section{Magnitude of Abortion Globally and in the United States}

Abortion is among the most important and controversial topics of our time. In 
1992, William Jefferson (Bill) Clinton stated, "abortion should be safe, legal and rare [1]." Yet, abortion was neither rare prior to the quote nor since. From 1973, when Roe vs. Wade legalized abortion, through 2017, an estimated 61,628,584 abortions were performed in the United States (U.S.) according to the Guttmacher Institute (GI) [2] [3]. The Centers for Disease Control (CDC) estimates there were 45,157,242 abortions from 1973-2016 [2] [3] [4]. The discrepancy is partially explained by the CDC's reliance on voluntary reporting from each state, and not all states report. California, for example, did not report abortions from 1998-2015 [2].

While this article focuses on abortion in the United States (U.S.), the topic is globally important. The number of abortions worldwide increased from 50.4 million annually in 1990-1994 to 56.3 million annually from 2010-2014 [5]. Thus, more than 1.3 billion abortions occurred globally over 25 years from 1990 through 2014. Abortion is not rare.

Abortions in the U.S. peaked in 1990 according to estimates from the GI and the CDC at 1,608,600 and 1,429,247, respectively, and have declined since. Surgical or procedural abortions are falling more rapidly over time than total abortions, as the percentage of abortions from medications such as mifepristone (RU486) followed by misoprostol more than doubled from $16.4 \%$ in 2008 to $39.4 \%$ in 2017 [2] [6]. Medically-induced abortions typically occur within the first 8 weeks of pregnancy, have the potential to surpass surgical abortions, and are a significant and growing threat to life in the womb.

As Pro-Life advocates consider approaches to reducing the loss of defenseless human life, it may be useful to better understand the "Pro-Choice" perspective. While faith is as an important variable in abortion, $30 \%$ of women undergoing abortion in the U.S. during 2014 identified as mainline or evangelical Protestant and $24 \%$ as Catholic [3].

This article includes three sections and a succinct plan for promoting life summarized in Figure 1. The first section, presented above, addresses the magnitude of abortion worldwide and in the U.S. The second section highlights key arguments from a "Perspective" published in Lancet, "The Art of Medicine: Abortion as a moral good" by Dr. Katie Watson [7]. Lancet is among the most widely read and respected medical journals worldwide. The author, Dr. Watson, serves as Associate Professor of Medical Social Sciences, Medical Education, and Obstetrics and Gynecology at Northwestern University Feinberg School of Medicine in Chicago, Illinois. She is also a lawyer and teaches law, ethics, and humanities to medical students and students in bioethics and humanities at Northwestern. Dr. Watson serves on the Board of the National Abortion Federation, the professional organization of independent abortion clinics, and the National Medical Council of the Planned Parenthood Federation of America. Thus, Dr. Watson is well qualified to present the Pro-Choice perspective on abortion.

The third section provides an alternative Judeo-Christian Pro Life viewpoint on abortion is provided. The response cites literature that captures the pre-conception humanity of the unborn child and the plans of a loving God whose directions 
Abortion: Facts, Perspectives and Plan.

1. Facts ${ }^{1-6,12,13}$

- More than 1.3 billion abortions globally 1990-2014

- More than 61 million abortions in the U.S. 1973-2017

- In 2017, 39\% of U.S. abortions were medical (not surgical)

- In 2014, >50\% of abortions occurred in women identifying as Protestant or Catholic

- Abortion per 1000 live births nine time higher in single than married women in the U.S.
2. Pro Choice Perspective ${ }^{7}$

- Love for pregnant women can motivate clinicians to provide abortions

- The fetus is not a person, so abortion doesn't harm a person

- Forced childbearing carries significant health risks

- Forced childbearing exacerbates poverty among low-income women

Thus, abortion is morally good
3. J udeo-Christian Pro Life Perspective 8-10 $^{-10}$

- All people are created in God's image

- God commanded humans to be fruitful and multiply

- Children are a blessing and reward from God

- God has a pre-conception life plan for everyone

Abortion is inconsistent with the plans of a loving Creator God

A Pathway for Life: Great Commandment and Great Commission

- Great Commandment: Love (obey) God; selflessly love others, meet them at points of need, AND

- Great Commission: Share God's love and grace with words of Truth in the power of the Spirit . . . Truth that illumines The Way to transform hearts and minds for Life

Figure 1. Legend. The figure summarizes the main sections of the paper including: 1) facts on the prevalence of abortion and selected characteristics provides of women having abortions 2) key principles underlying the notion of abortion as a moral good supporting the Pro Choice perspective 3) key facets of the Judeo-Christian Pro Life perspective 4) a potential Judeo-Christian response women considering abortion centered in unconditional love and timeless truth.

and commands lead to an abundant life based on unconditional love and surrender to his perfect will [8] [9] [10]. The concluding comments provide a potential pathway, centered in unconditional or agape love to foster greater harmony and cooperation between women contemplating abortion and Judeo-Christian Pro Life advocates that minimizes abortion.

\section{Abortion as a Moral Good: Key Facets of the Pro Choice Perspective}

1) The Christian and biblical foundation for opposing and supporting abortion are both valid. Dr. Watson begins with medical students hearing from two Christian physicians. One physician opposes abortion based on the biblical principle of "love your neighbor as yourself", since he views both the pregnant woman and the fetus as neighbors. The other physician sites the biblical principle of "do unto others as you want done to you" and believes that God is proud of her for performing abortions [7].

2) Framing the discussion of abortion as a moral good. Dr. Watson then raises a question that leads to an exposition of evidence for abortion as a moral good, "How might we correct the false impression that abortion opponents are the only ones thinking about the ethics of abortion?"

Challenging the position of the woman's status as legal and the fetus' status as moral. "The first step is to remember that the conclusion women are full people entitled to self-determination begins as a moral argument and ends as a legal argument. Typically, consideration of the status of women is categorised as 'legal' and consideration of the status of embryos and fetuses is categorised as 'moral', when really each...is both moral and legal." 
"The second step is to help people understand the secular ethics reasoning that leads those who support abortion access to conclude that abortion is ... morally good. In medical settings, this conversation might be destigmatised by articulating how the traditional medical ethics analysis of principlism." [a practical approach to addressing moral dilemmas] "supports abortion access."

3) Does abortion do harm to a person or patient? "The principlist analysis must address non-maleficence first-does abortion 'do harm' to a person or a patient? ...People who think abortion is morally acceptable say it does not (do harm to a person), because they reject what abortion opponents call the 'substantial identity' argument ... They rarely claim that an embryo's potential to become a person ... is of no importance. But just as potentiality does not give an acorn the same value as an oak tree, they conclude that it is reasonable to put embryos and people in different categories ... Concluding that abortion does not violate the principle of non-maleficence makes it morally acceptable."

4) A woman's decision to terminate pregnancy is morally acceptable. "To become a person, it (fetus) must be nourished by, and make a bloody exit from, a woman...Assigning rational, sentient, biologically independent women a higher moral status than biologically dependent embryos or fetuses leads to the conclusion that forced childbearing is immoral, and that a woman's decision to end an unwanted pregnancy is a morally acceptable act."

5) Abortion serves the principle of beneficence. "Childbearing dramatically alters a woman's identity and life experience, and in the USA childbirth carries a risk of death about 14 times higher than abortion ... Clinicians who provide abortions honour the medical ethics principle of beneficence by preventing the harms of forced childbearing and unsafe abortion."

Children exacerbate poverty. "Abortion access is a component of economic justice because parenthood is expensive. In the USA, $49 \%$ of abortion patients have incomes below the poverty line and an additional $26 \%$ have low incomes; $73 \%$ of abortion patients list 'can't afford a baby now' as one of their reasons, and $23 \%$ list it 'as the most important reason' for having an abortion. Until social programmes remove economic barriers to childrearing, allowing low-income women and families the option of abortion prevents them from being pushed even further into poverty."

6) Two views with a focus on mutual understanding and respect. "Those who say we shouldn't talk about abortion because we're unlikely to convince each other have forgotten that sometimes we talk not to persuade, but to understand...understanding is what prevents us from vilifying those who disagree, and retaining respect and compassion for patients and colleagues who see the world differently...”

\section{The Judeo-Christian Pro Life Perspective and Response to Abortion as a Moral Good}

1) The fetus has personal status with God who has foreknowledge of and a purpose for everyone. 
Psalm 139:13-16 (King David 1000 BC). For you created my inmost being, you knit me together in my mother's womb...My frame was not hidden from you when I was made in the secret place...your eyes saw my unformed body. All the days ordained for me were written in your book, before one of them came to be [9].

Isaiah 49:5 (Isaiah 710 BC). "And now, says the Lord, who formed me from the womb to be his servant, to bring Jacob back to him so that Israel might be gathered to him; for I am honored in the sight of the Lord, and my God is my strength" [9].

Jeremiah 1:5 (Jeremiah $~ 600 \mathrm{BC}$ ). "Before I formed you in the womb I knew you, before you were born I set you apart; I appointed you as a prophet to the nations" [9].

Ephesians 2:10 (NIV 1984, Apostle Paul 60 AD]). "For we are God's handiwork, created in Christ Jesus to do good works, which God prepared in advance for us to do" [9].

Abortion rejects God's command to be fruitful and multiply.

Genesis 1:27-28a. "So God created mankind in his own image, in the image of God he created them; male and female he created them. God blessed them and said to them, 'Be fruitful and increase in number; fill the earth and subdue it'”... [10].

Genesis 9:1. After the flood ... "Then God blessed Noah and his sons, saying to them, 'Be fruitful and increase in number and fill the earth"' [9].

2) Abortion limits our heritage and reward from God.

Psalm 127:3. "Children are a heritage from the Lord, offspring a reward from him..." [10].

Biblical perspective on sacrificial (agape) love and relevance to abortion. Mother Teresa sacrificially loved infants and children rejected by the world. On February 3, 1994, she spoke at the National Prayer Breakfast of God's sacrificial love for us as an example of the sacrificial love we should have for each other. Excerpts from her comments are provided below.

"Let us thank God for the opportunity He has given us today to pray together...especially to pray for peace, joy and love...God loved the world so much that He gave His son (John 3:16) — it was a giving... Jesus died on the Cross because that is what it took for Him to do good to us-to save us from our selfishness in sin. He gave up everything to do the Father's will-to show us that we too must be willing to give up everything to do God's will-to love one another as He loves each of us (John 13:34)."

3) A societal cost to abortion. "But I feel that the greatest destroyer of peace today is abortion, because it is a war against the child, a direct killing of the innocent child...And if we accept that a mother can kill even her own child, how can we tell other people not to kill one another?"

"How do we persuade a woman not to have an abortion? As always, we must persuade her with love, and we remind ourselves that love means to be willing to give until it hurts. Jesus gave even His life to love us. So, the mother who is 
thinking of abortion, should be helped to love, that is, to give until it hurts her plans, or her free time, to respect the life of her child. The father of that child, whoever he is, must also give until it hurts...Any country that accepts abortion is not teaching its people to love, but to use any violence to get what they want. This is why the greatest destroyer of love and peace is abortion."

4) A beautiful alternative to abortion. "I will tell you something beautiful. We are fighting abortion by adoption-by care of the mother and adoption for her baby. We have saved thousands of lives...So we always have someone tell the mothers in trouble: 'Come, we will take care of you, we will get a home for your child.' And we have a tremendous demand from couples who cannot have a child."

5) Does abortion harm a person (maleficence)? From a biblical perspective, the answer is "yes", since God has a pre-conception life plan for everyone created in His image. Yet, many Pro Life advocates accept that abortion is permissible if the life of the mother is truly at risk, i.e., many abortion opponents acknowledge the rights of the mother as greater than those of her unborn child.

The relative legal rights of the pregnant woman and her unborn child. In 2018, there were 3,788,235 births and about 700 deaths related to complications of pregnancy and childbirth in the U.S [11] [12]. With abortion, the risk of death is virtually $100 \%$ for the fetus versus $\sim 0.0018 \%$ for the mother who carries a pregnancy to term and delivers. Thus, the legal rights of the mother must be more than 5000 times greater than those of the fetus to justify abortion on the basis of the mother's risk of death with child birth. In other words, in most abortions, the fetus has no rights.

6) Does abortion serve the principle of beneficence? Dr. Watson proposes that abortion is beneficent, since the mother is not forced into childbearing and the risks of delivery and greater poverty [7]. Yet, few pregnancies are terminated because of rape but rather from consensual sex between the pregnant woman and the father. Sex between and men and women of child-bearing potential include possible pregnancy and economic effects. Child-bearing and related costs most often reflect a voluntary decision.

The biblical perspective is that sex occurs in the context of marriage and relevance to abortion. Married women in the U.S. undergo about 41 induced abortions per 1000 live births in contrast to 373 abortions per 1000 live births in unmarried women-a nine-fold difference [13]. Thus, marriage between a woman and a man is one of the most powerful factors affecting the probability of abortion.

The solution to sin (rebellion against God) is not more sin [9] [10]. Christians recognize that we have all sinned and fall short of God's glory (Romans 3:23). None of us is righteous on our own (Romans 3:10). Rather, righteousness comes from faith in Jesus (Messiah) to all who believe (Romans 3:22). Jesus died for all sins for all time (past, present, and future), yet adding the sin of abortion to the sin of adultery or fornication is not beneficial. Forgiveness of sin does not erase adverse consequences to us and others resulting from rebellion against God (2 
Samuel 12:1-18).

\section{A Potential Collaborative Pathway for Life.}

A shortcoming of many Pro-Life advocates. As Dr. Watson stated, "Until social programmes remove economic barriers to childrearing, allowing low-income women and families the option of abortion prevents them from being pushed even further into poverty" [7].

What is the Christian Church doing to address real-life challenges experienced by pregnant women considering abortion? Could the Christian Church do more in following Mother Teresa's example of sacrificial love for women considering abortion [8]? In other words, we have an opportunity to match our passion for life with resources, training and love for pregnant women and the child's father, as we assist them in meeting their obligations in a God-honoring way.

Is Abortion: a moral good? The answer is determined by world view. In most Western countries, there are two primary world views, i.e., human-centered or secular and God-centered or Judeo-Christian. As a Christian who accepts the Bible as the inspired word of God (2 Timothy 3:16), abortion is not a moral good. While God gives us free will and permits us to act contrary to His Word, there are consequences. Solomon was given more wisdom by God than any other person (2 Chronicles 1:7-12). He wrote, "There is a way that appears to be right, but in the end it leads to death" (Proverbs 14:12) [10]. The Pro Choice perspective emphasizes the woman's right to choose. Solomon wrote, “Trust in the Lord with all your heart and lean not on your own understanding (Proverbs 3:5) [9]. And, Jeremiah wrote, "LORD, I know that people's lives are not their own; it is not for them to direct their steps" (Jeremiah 10:23) [10].

Basing moral and legal decisions on human understanding rather than God's wisdom is perilous-bondage to and destruction by sin. By contrast, there is liberty, blessing, and joy in understanding and living within God-given boundaries. I run in the path of your commands, for you have set my heart free (Psalm 119:32) [9]. I will walk about in freedom, for I have sought out your precepts (Psalm 119:45) [9]. If we love God, then we cannot live in persistent defiance to his word (John 14:15) and we will love others (1 John 4:20), since all humans are created in his image.

The Judeo-Christian community can provide more active, unconditional love in Promoting Life?

\section{Conclusions}

As a Christian, I am compelled to promote life with the unconditional love of Jesus Christ (Messiah), which was beautifully exemplified through the life of His servant, Mother Teresa. In the quest for mutual understanding, proponents of both Choice and Life are encouraged to carefully consider her message at the National Prayer Breakfast in 1994 [8].

As with most of life's personal, social, and political dilemmas, the Great Commandment and the Great Commission are timeless foundations for members of the Judeo-Christian community. Adopting the model described by Mother 
Teresa, unconditional love can be exemplified by Judeo-Christian counsellors who are readily available, safe and supportive places to stay, and excellent prenatal care all of which are provided at no cost or affordable subsidized cost. The pregnant woman, preferably with the support of her family and the child's father then decides whether to raise the child with continued support as needed for medical care and basic needs including shelter, education, job training, etc., or to offer her child for adoption to a loving family. Those of us who call on the Name of the Lord/Jehovah are commanded to show unconditional love for others. The process outlined provides a starting point for translating unconditional love to constructive action. Christians are commissioned to share the grace of God and the truth of the Word in the power of the Spirit. These divine tools are The Way to change hearts and minds for Life.

\section{Disclaimer}

The statements in this report are those of the author and do not necessarily represent the official position of the American Medical Association.

\section{Conflicts of Interest}

The author declares no conflicts of interest regarding the publication of this paper.

\section{References}

[1] Flanagan, C. (2019) Losing the Rare in "Safe, Legal and Rare". The Atlantic. December 6, 2019.

https://www.theatlantic.com/ideas/archive/2019/12/the-brilliance-of-safe-legal-and$\underline{\text { rare/603151/ }}$

[2] Abortion Statistics-United States Data and Trends 1973-2017. National Right to Life. https://nrlc.org/uploads/factsheets/FS01AbortionintheUS.pdf

[3] Induced Abortion in the United States-Fact Sheet. Guttmacher Institute, September 2017. https://www.guttmacher.org/sites/default/files/factsheet/fb induced abortion.pdf

[4] Jatlaoui, T.C., et al. (2019) Abortion Surveillance-United States, 2016. Morbidity and Mortality Weekly Report (MMWR), 68, 1-41.

https://doi.org/10.15585/mmwr.ss6811a1

[5] Sedgh, G., Bearak, J., Singh, S., Bankole, A., Popinchalk, A., Ganatra, B., Rossier, C., Gerdts, C., et al. (2016) Abortion Incidence between 1990 and 2014: Global, Regional and Subregional Levels and Trends. The Lancet, 388, 258-267. https://doi.org/10.1016/S0140-6736(16)30380-4

[6] Mifiprex ${ }^{\circledR}$ (Mifepristone) Highlights of Prescribing Information. U.S Food and Drug Administration (FDA). https://www.accessdata.fda.gov/drugsatfda docs/label/2016/020687s020lbl.pdf

[7] Watson, K. (2019) The Art of Medicine: Abortion as a Moral Good. The Lancet, 393, 1196-1197. https://doi.org/10.1016/S0140-6736(19)30581-1

[8] The 42nd Annual National Prayer Breakfast (1994) Congressional Record, 140. https://www.govinfo.gov/content/pkg/CREC-1994-05-02/html/CREC-1994-05-02-p $\underline{\mathrm{t} 1-\mathrm{PgS} 16 . \mathrm{htm}}$ 
[9] The Holy Bible (1984) New International Version (NIV) 1984. Zondervan, Grand Rapids, Michigan.

[10] The Holy Bible (2011) New International Version 2011. Zondervan, Grand Rapids, Michigan.

[11] Hamilton, B.E., Martin, J.A., Osterman, M.J.K. and Rossen, L.M. (2019) Births: Provisional Data for 2018. Vital Statistics Surveillance Report, Report No. 7. https://www.cdc.gov/nchs/data/vsrr/vsrr-007-508.pdf

[12] Reproductive Health: Pregnancy-Related Deaths. Centers for Disease Control and Prevention.

https://www.cdc.gov/reproductivehealth/maternalinfanthealth/pregnancy-relatedm ortality.htm

[13] Jatlaoui, T.C., et al. (2018) Abortion Surveillance-United States, 2015. Morbidity and Mortality Weekly Report (MMWR), 67, 1-45.

https://www.cdc.gov/mmwr/volumes/67/ss/ss6713a1.htm https://doi.org/10.15585/mmwr.ss6713a1 